Europe's Journal of Psychology, 6(3), pp. 174-195

www.ejop.org

\title{
A Framework for Thinking about the (not-so-funny) Effects of Sexist Humor
}

Julie A. Woodzicka

Washington and Lee University

Thomas E. Ford

Western Carolina Univ ersity

\section{Abstract}

The prevalence of sexist humor in popular culture and its disguise as benign amusement or "just a joke" give it potential to cultivate distress and harassment for women and to facilitate tolerance of sexism and discriminatory behavior among men. Thus, understanding the social consequences of sexist humor is a critical project for research in social psychology. The purpose of our paper is to provide researchers with a conceptual framework for organizing and evaluating empirical research and theories on sexist humor. We divided research on sexist humor into two categories: direct effects and indirect effects. Research on direct effects addresses questions about variables that moderate the interpretation of sexist humor as benign amusement versus a reprehensible expression of sexism. Research on indirect effects considers questions about the broader social consequences of exposure to sexist humor. For instance, "how does exposure to sexist humor affect the way people think about women and their perceptions of discrimination against women?" and "does sexist humor promote sexist behavior among men?" For each category of research, we describe representative empirical research and theoretical frameworks used to guide that research. Importantly, we also raise important issues or questions that require further empirical research or theoretical development. We hope that this research will cultivate further interest in theoretically guided empirical research on sexist humor.

Keywords: sexist humor, sexism, hostile work environment, effects of humor 
In a recent National Basketball Association (NBA) playoff game post-game show, commentator Charles Barkley teased a camerawoman because he was able to do more push-ups than she. In that context, Barkley joked with his co-host Kenny Smith, "How do you fix a woman's watch? You don't. There's a clock on the stove" (Estrada, 2009). Charles Barkley's joke exemplifies sexist humor.

Sexist humor demeans, insults, stereotypes, victimizes, and/or objectifies a person on the basis of his or her gender (LaFrance \& Woodzicka, 1998). Importantly, women are more frequently the target of aggressive humor and the object of sexual humor than are men (Cantor \& Zillmann, 1973). The popularity of sexist humor is seen in mass media, workplaces, and informal social interactions. Access to the internet has increased the ease with which sexist jokes can be located and distributed. For example, type the words "sexist joke" into any web browser and a library of female denigration immediately appears. Sexist humor communicates denigration of women while simultaneously trivializing sex discrimination under the veil of benign amusement (Bill \& Naus, 1992). By communicating denigration of women through levity sexist humor makes ambiguous how one should interpret a message (Johnson, 1990) like Charles Barkley's joke. Machan (1987) articulated this paradox, suggesting that what is funny to one person is "the height of bad taste to another" (p. 218).

Research on sexist humor can be divided into two categories. The first category addresses questions about variables that foster the interpretation of humorous disparagement like Barkley's joke as funny, benign horseplay versus "the height of bad taste"-an inexcusable expression of sexism. In the present review, we refer to the immediate interpretations of and emotional reactions to sexist humor as direct effects. The second category of research addresses the broader social consequences of exposure to sexist humor. For instance, we review how exposure to sexist humor affects the way that people think about women and the extent to which sexist humor promotes sexist behavior among men. We refer to such broader social consequences as indirect effects of sexist humor.

The purpose of our paper is to review contemporary research on the direct and indirect effects of sexist humor. For each category of research, we describe representative empirical research and theoretical frameworks used to conceptualize or guide that research. Importantly, we also delineate novel and potentially fruitful directions for future investigations. 


\section{Direct Effects of Sexist Humor}

Whether you appreciate Charles Barkley's joke, that is, interpret it as benign amusement, or consider it an offensive expression of sexism depends on the degree to which you are willing to overlook or excuse the underlying sentiment. Historically, humor researchers have emphasized the role that sex differences and attitudes toward women play in moderating appreciation of sexist humor. Furthermore, humor appreciation has been operationally defined as amusement with sexist humor (Brodzinsky, Barnet, \& Aiello, 1981; Chapman \& Gadfield, 1976; Hassett \& Houlihan, 1979; Losco \& Epstein, 1975; Love \& Deckers, 1989; Neuliep, 1987, Priest \& Wilhelm, 1974; Ryan \& Kanjorski, 1998), perceived offensiveness of sexist humor (Ford, 2000; Greenwood \& Isbell, 2002; Hemmasi, Graf, \& Russ, 1994; LaFrance \& Woodzicka, 1998; Ryan \& Kanjorski, 1998), and willingness to tell sexist jokes (Ryan \& Kanjorski, 1998; Thomas \& Esses, 2004).

Sex Differences in Sexist Humor Appreciation

Social identity theory (Tajfel \& Turner, 1986) provides a framework for understanding empirical findings on the relationship between biological sex and sexist humor appreciation. Social groups are viewed as competing for recognition, not necessarily for material resources. This recognition is known as positive distinctiveness. When a group is recognized as superior to a relevant out-group along some valued dimension, it has achieved positive distinctiveness. Because social groups value positive distinctiveness, they will use various means for attaining it. One such means is disparagement humor (Barron, 1950; Bourhis, Gadfield, Giles, \& Tajfel, 1977). Bourhis et al. (1977) suggested that disparagement humor allows people to maintain positive social identities-feelings of superiority over out-groups. They proposed that, "anti-out-group humor can, through out-group devaluation and denigration, be a creative and potent way of asserting in-group pride and distinctiveness from a dominant out-group" (p. 261).

According to social identity theory, men and women construct gender identities in an effort to differentiate themselves from one another. As a result, they should appreciate only humor that positively distinguishes the in-group from the out-group (Duncan, Smeltzer, \& Leap, 1990; Hemmasi, Graf, \& Russ, 1994; Smeltzer \& Leap, 1988). Not surprisingly, then, men view sexist humor as funnier and less offensive than women view it (Chapman \& Gadfield, 1976; Hassett \& Houlihan, 1979; Losco \& Epstein, 1975; Love \& Deckers, 1989; Mundorf, Bhatia, Zillmann, Lester, \& Robertson, 1988; Neuliep, 1987, Priest \& Wilhelm, 1974). Love and Deckers (1989), for instance, 
found that women rated sexist cartoons as less funny than men did because they identified with the female cartoon victim. Furthermore, women are more likely than men to view sexist jokes as constituting harassment (e.g., Bell, McLaughlin, \& Sequeira, 2002; Frazier, Cochran, \& Olson, 1995; Hemmasi \& Graf, 1998; Smeltzer \& Leap, 1988). Smeltzer and Leap (1988) found that women considered sexist humor in the workplace as more inappropriate than men did. Similarly, Frazier et al. (1995) reported that $74 \%$ of the women they surveyed considered sexual jokes and teasing to be harassment, whereas only $47 \%$ of the men felt the same.

\section{Attitudes tow ard Women and Sexist Humor Appreciation}

Consistent with La Fave's vicarious superiority theory (La Fave, 1972; La Fave, Haddad, \& Maesen, 1976) and Zillmann and Cantor's (1972; 1976) disposition theory, the differences in humor perceptions between men and women may be due more to gender attitudes than to an in-group bias based on biological sex (Hemmasi et al., 1994; Sev'er \& Ungar, 1997). A central hypothesis of disposition theory that has received considerable empirical support is that the degree of amusement elicited by disparagement humor is related positively to the degree to which one holds negative attitudes toward the disparaged target (e.g., Cantor \& Zillmann, 1973; La Fave, McCarthy, \& Haddad, 1973; McGhee \& Duffey, 1983; Wicker, Barron, \& Willis, 1980). Specifically, Zillmann and Cantor (1976/1996) proposed that, "Humor appreciation varies inversely with the favorableness of the disposition toward the agent or entity being disparaged" (pp. 100-101). For thorough reviews of disposition theory and other "superiority" theories and their origins, see Ferguson and Ford (2008), Gruner (1997), Keith-Spiegel (1972), Morreall (1983) and Zillmann (1983).

In the context of sexist humor, Chapman and Gadfield (1976) found that, for both men and women, appreciation of sexist cartoons was negatively related to the extent to which participants endorsed women's liberation ideology. Research that more directly measured attitudes toward women has revealed similar results. Regardless of sex, people enjoy sexist humor insofar as they have negative (sexist) attitudes toward women (e.g., Butland \& IVy, 1990; Henkin \& Fish, 1986; Moore, Griffiths, \& Payne, 1987).

The development of Glick and Fiske's (1996) Ambivalent Sexism Inventory (ASI) has allowed researchers to make further advances in our understanding of the relationship between attitudes toward women and sexist humor appreciation. The ASI measures two types of sexist attitudes, hostile sexism and benevolent sexism. Hostile sexism refers to antagonism or animosity tow ard women, whereas benevolent 
sexism refers to subjectively positive attitudes toward women that are rooted in masculine dominance and conventional stereotypes (Glick \& Fiske, 1996).

LaFrance and Woodzicka (1998) found that, for women, hostile sexism was a significant predictor of amusement with sexist jokes. In addition, hostile sexism, but not benevolent sexism, significantly predicted felt Duchenne smiling-smiling that reveal truly positive affect-in response to sexist humor. Subsequent research also has found that both men and women appreciate sexist humor insofar as they are high in hostile sexism (Eyssel \& Bohner, 2007; Ford, 2000; Ford, Johnson, Blevins, \& Zepeda, 1999; Greenwood \& Isbell, 2002; Thomas \& Esses, 2004). Greenwood and Isbell (2002), for instance, found that men and women high in hostile sexism were more amused by and less offended by "dumb blonde" jokes than were men and women low in hostile sexism. Similarly, Thomas and Esses (2004) found that men reported more enjoyment of sexist jokes and a greater likelihood of telling those jokes insofar as they were high in hostile sexism.

Research on the role of benevolent sexism in predicting sexist humor appreciation has revealed more complicated findings. For men, benevolent sexism predicts amuse ment ratings in a straightforward fashion (Eyssel \& Bohner, 2007; Greenwood \& Isbell, 2002). Men higher in benevolent sexism appreciate sexist humor more than those low in benevolent sexism. Women high on benevolent sexism, on the other hand, appear to find sexist jokes less amusing than their less benevolently sexist counterparts (Greenwood \& Isbell, 2002). Indeed, LaFrance and Woodzicka (1998) found that benevolent sexism correlated positively with nonverbal expression of disgust with sexist jokes. As Greenwood and Isbell (2002) pointed out, the degree to which women high in benevolent sexism appreciate sexist humor is similar to that of women who endorse feminist social/political ideologies.

Future Directions for the Study of Direct Effects

Contemporary research on the direct effects of exposure to sexist humor has provided valuable insights into the critical variables that moderate the interpretation of sexist humor as benign amusement versus a reprehensible expression of sexism. Specifically, research has revealed that men more than women are willing to overlook the underlying sentiment of sexist humor for the sake of amusement. Also, both men and women who have sexist attitudes are particularly likely to be amused rather than offended by sexist humor.

We propose that future research can build upon these findings by expanding the scope of investigations in a number of ways. First, research could expand on the 
measurement of humor appreciation to assess other emotional responses to sexist humor. Second, research could expand beyond the use of self-report measures to include non-verbal measures of reactions to sexist humor. Non-verbal measures potentially could provide a more complete, accurate assessment of emotional reactions to sexist humor. Third, research could consider more fully women's reactions to sexist humor.

Measuring emotional responses other than humor appreciation. Research guided by disparagement humor theories has typically measured humor appreciation as the primary dependent variable. Measuring humor appreciation alone is problematic, as it negates the investigation of a wider variety of potential affective responses to sexist humor. Indeed, research has largely ignored negative emotional responses to sexist humor such as embarrassment, disgust, guilt, anger, and frustration (but see La France \& Woodzicka, 1998). Such negative affective responses are not theoretically irrelev ant-disparagement humor theories are not silent on such affective reactions. According to both social identity theory and disposition theory sexist humor should meet with negative affective reactions (not simply lack of amusement) under certain conditions. Thus, we recommend that researchers "unpack" the diverse range of emotions that are immediately felt upon exposure to sexist humor. This research would contribute to a more complete picture of people's "in-the-moment" reactions to sexist humor.

Measuring nonverbal responses to sexist humor. Humor appreciation is typically measured using self-reports on rating scales. The exception to this is a small handful of studies that incorporated facial expression in addition to funniness ratings (Brodzinsky, Barnet, \& Aiello, 1981; LaFrance \& Woodzicka, 1998; Olson \& Roese, 1995). We propose that the reliance on self-report measures of amusement may not always provide an accurate gauge of actual amusement or other emotional reactions to sexist humor. Research participants may give false reports because of demand characteristics in a given study or because of social desirability concerns more generally.

In contrast, because nonverbal responses can be difficult to regulate, they could contribute to a more nuanced picture of emotional reactions to sexist humor. For instance, Brodzinsky et al. (1981) rated participants' spontaneous expressions of mirth to three types of cartoons using a 4 point scale based on smiling ( 1 = blank expression, 2 = slight smile, 3 = full smile, 4 = chuckling or laughter). In addition, they collected standard self-report ratings of amusement. Findings revealed differences in humor appreciation depending on whether amusement was measured by selfreport or facial expression. The self-report ratings indicated that female participants 
enjoyed absurd cartoons significantly more than cartoons disparaging either males or females. However, the ratings based on smiling behavior indicated that female participants felt equally amused by the three types of cartoons. Similarly, LaFrance and Woodzicka (1998) found that sexist and neutral jokes differentially affected funniness ratings but not Duchenne smiling. These findings suggest that the measurement of smiling and other nonverbal responses should reveal more complex and subtle emotions, and shed new light on how sexist humor is experienced emotionally as a function of one's sex and attitudes tow ard women. Accordingly, we recommend that researchers measure a variety of non-verbal responses to disparagement humor such as facial expressions and gestures because they are generally less reactive and can reflect both positive and negative affective states (LaFrance \& Woodzicka, 1998).

Women's reactions to sexist humor. We propose that an important oversight in the literature is that there has been little empirical research directed at how women respond to sexist humor (Nelson, 2006). Like research on other types of prejudice, research on sexist humor has largely ignored the target's perspective (Swim \& Stangor, 1998). Notably, LaFrance and Woodzicka (1998) acknowledged the social relev ance of sexist humor for women and initiated the study of women's responses to sexist humor. They found that hearing sexist jokes had adverse emotional effects on women. Specifically, women reported feeling more disgusted, angry, and surprised in response to sexist jokes than to non-sexist jokes. Also, their nonverbal facial expressions revealed negative affective reactions. Compared to women hearing jokes about attorneys, women hearing sexist jokes were more likely to roll their eyes, displaying feelings of contempt, and to cover their mouths with their hand, showing signs of embarrassment.

Furthermore, LaFrance and Woodzicka (1998) found that women's levels of hostile sexism and their degrees of identification with women moderated their emotional responses to sexist jokes. Hostile sexism was positively related to self-report and nonverbal affective reactions to sexist jokes. In addition, level of identification with women was associated with less amusement with sexist jokes and more non-verbal displays of negative emotion such as frowning. In sum, women who endorsed nonsexist attitudes or who identified strongly with women had especially adverse emotional reactions to sexist jokes.

Extending the findings LaFrance and Woodzicka (1998), future research could determine if women differentially identify with particular sub-groups of women and therefore respond differently to sexist humor that targets those sub-groups. Unlike men, women have the dual status of both the recipient and the object of sexist 
humor (Greenwood \& Isbell, 2002). Thus, according to both disposition theory (Zillmann \& Cantor, 1976/1996) and social identity theory (Tajfel \& Turner, 1986) women would have to dissociate or disidentify with the specific humor target in order to excuse the underlying sentiment of sexist humor and find it amusing. Thus Greenwood and Isbell (2002) may have found that women high in hostile sexism enjoyed "dumb blonde" jokes because they did not identify with the subtype of women targeted by the jokes.

Glick and Fiske (1996) suggested that hostile sexism is understood within a context of a backlash against feminism. Thus, we propose that women high in hostile sexism particularly disidentify with feminists. If women high in hostile sexism particularly disidentify with feminists, they should be more likely to accept sexist humor that disparages feminists than humor that disparages women in general or other "nonnorm challenging" sub-groups of women (e.g., blondes, housewives). Humor targeting women in general, however, may be associated with disapproval and negative affect. In keeping with this hypothesis, preliminary data we recently collected revealed a stronger negative relationship between women's level of hostile sexism and identification with feminists than with women in general. Further, the positive relationship between hostile sexism and amusement ratings for feminist jokes was stronger than the relationship between hostile sexism and ratings of sexist jokes that targeted women in general.

\section{Indirect Effects of Sexist Humor}

In addition to having direct effects, sexist humor has broader social consequences, or indirect effects, on both women and men. Specifically, sexist humor potentially can create distressing, hostile work environments for women (Boxer \& Ford, in press; Duncan, Smeltzer, \& Leap, 1990; Hemmasi, et al., 1994). Also, sexist humor affects the ways that men think about women and perceive discrimination against them (Ford, 2000; Ford, Wentzel, \& Lorion, 2001; Ryan \& Kanjorski, 1998) as well as their willingness to engage in subtle sexist behavior (Ford, Boxer, Armstrong, \& Edel, 2008).

The Impact of Sexist Humor in Creating a Hostile Work Environment

Sexist jokes have been construed as a form of sexual harassment because they can contribute to a hostile work environment (Baker, Terpstra, \& Larntz, 1990; Fitzgerald, Swam, \& Fischer, 1995; Gutek \& Koss, 1993). Indeed, in 1995, Chevron Corporation agreed to pay over two million dollars to settle sexual harassment charges brought by four female employees what said that they had been targeted with offensive jokes, e-mail messages, and comments about their clothes and bodies (Lewin, 1995). 
In this case and others, employers have been held financially liable for behavior that might have been delivered as a joke, but that others viewed as harassing. In a 1995 survey of 4,000 people, $71 \%$ of respondents considered the telling of gender stereotypes jokes in the workplace to be sexual harassment (Frazier, Cochran, \& Olson, 1995). This number reflects a growing consensus that sexist humor constitutes a form of sexual harassment. In 1987 only $20 \%$ of respondents perceived sexist jokes as harassment (Terpstra \& Baker, 1987). Further, women consider the telling of sexist jokes at work to be more inappropriate than do men (Hemmasi et al, 1994; Smeltzer \& Leap, 1988) and sexist jokes are more likely to be viewed as sexual harassment when coming from a male supervisor than by a male co-worker (Hemmasi et al, 1994).

Like other forms of gender harassment, sexist humor negatively affects relationships among co-workers. Duncan (1982) for instance, found that sexist humor decreased cohesiveness among co-workers. Sexist humor may also reinforce status differences among workers, particularly men (who are often the joke tellers) and women (the objects of sexist jokes). These dynamics are thought to lead to further power imbalances (Duncan, 1982; Sev'er \& Ungar, 1997).

Sexist humor might also affect how people perceive sexism in the workplace. Ford (2000) found that sexist jokes increased tolerance for sexist behavior in the workplace among participants high in hostile sexism. He exposed male and female participants, who were either high or low in hostile sexism, to sexist jokes, sexist statements, or neutral jokes. Participants then read a vignette in which a male supervisor treated a new female employee in a patronizing manner that was inappropriate and potentially threatening in the workplace. After reading the vignette, participants rated the offensiveness of the supervisor's behavior. The results indicated that exposure to sexist jokes led to greater tolerance of the supervisor's sexist behavior in comparison to exposure to neutral jokes or comparable nonhumorous sexist statements, but only for participants high in hostile sexism.

Sexist Humor and Discrimination against Women

A growing body of research has documented that, among sexist men, exposure to sexist humor uniquely fosters a social climate of discrimination against women. Ford and Ferguson's (2004) prejudiced norm theory explains these findings and delineates the mediating processes by which sexist humor functions as a "releaser" of prejudice.

Sexist humor and stereotypes about women. Weston and Thomsen (1993) found that participants made more stereotypical evaluations of men and women after 
watching sexist comedy skits than after watching neutral comedy skits. These findings suggest that exposure to sexist humor activ ates gender stereotypes.

As Ford and Ferguson (2004) noted, however, Weston and Thomsen's study lacked the non-humorous control condition necessary to make conclusions about the unique effects of humor as a medium for communicating disparagement. In fact, Hansen and Hansen (1988) found that exposure to non-humorous stereotypes of men and women increased the accessibility and use of gender stereotypes. Furthermore, Weston and Thomsen's study failed to include individual differences in attitu des tow ard women as a potential moderator variable.

In a study that addressed these methodological problems, Ford, et al. (2001) demonstrated that, even among men high in hostile sexism, exposure to sexist humor did not affect the evaluative content of men's stereotypes about women relative to comparable non-humorous disparagement or neutral humor. Thus, to date, there is no evidence that exposure to sexist humor uniquely affects stable, internal knowledge structures, such as stereotypes and attitudes toward women (see also Olson, Maio \& Hobden, 1999).

Sexist humor and prejudiced norm theory. Although exposure to sexist humor may not affect internal sources of self-regulation (i.e., attitudes and stereotypes), it can still affect men in ways that have negative social consequences for women. As mentioned earlier, Ford (2000) demonstrated that exposure to sexist humor was associated with greater tolerance of a subsequently encountered sexist event. In addition, Ryan and Kanjorski (1998) found that, among men, enjoyment of sexist humor correlated positively with acceptance of rape myths and endorsement of adversarial sexual beliefs.

Ford and Ferguson (2004) proposed their "prejudiced norm" theory to explain these findings and generate new hypotheses about the social consequences of exposure to sexist humor. Prejudiced norm theory is built on three interrelated propositions. First, humorous communication activates a conversational rule of levity-to switch from the usual serious mindset to a non-serious humor mindset for interpreting the message. According to Berlyne (1972), "Humor is accompanied by discriminative cues, which indicate that what is happening, or is going to happen, should be taken as a joke. The ways in which we might react to the same events in the absence of these cues become inappropriate and must be withheld" (p. 56). In the case of disparagement, humor cues communicate that the message is non-threatening and can be interpreted in a playful, non-serious mindset. As Zillmann and Cantor 
(1976/1996) suggested, the "club over the head" is funny when the protagonists are clowns in cartoons but not when they are police officers responding to a riot.

Second, by making light of the expression of prejudice, disparagement humor communicates an implicit "meta-message" (Attardo, 1993) or normative standard that it is acceptable in this context to relax the usual "critical sensitivities" and treat such discrimination in a less critical manner (Husband, 1977). For example, Gollob and Levine (1967) found that when participants were asked to focus on the content of highly aggressive cartoons, they reported appreciating the cartoons less. Humor indicates a shared understanding of its meta-message only if the recipient approves of the humor (Fine, 1983; Kane, Suls, \& Tedeschi, 1977). So, if the recipient approves of disparagement humor-that is, switches to a non-serious humor mindset to interpret the expression of prejudice-he or she tacitly consents to a shared understanding (a social norm) that it is acceptable in this context to make light of discrimination against the targeted group. In keeping with this hypothesis, Ryan and Kanjorski (1998) found that men who were exposed to sexist jokes reported greater acceptance of rape myths and violence against women but only when they found the jokes amusing and inoffensive-that is, when they interpreted the jokes in a nonserious humor mindset. Ford (2000) manipulated humor type (sexist, control) and critical mindset (serious, control) to see if critical mindset would affect amusement ratings. As expected, those in the critical mindset condition rated the jokes as funnier than those in the control condition.

Third, one's level of prejudice toward the disparaged group affects reactions to disparagement humor. Insofar as recipients are high in prejudice toward the disparaged group, they will interpret disparagement humor through a non-serious humor mindset (Zillmann \& Cantor, 1976/1996). Thus, upon exposure to disparagement humor, people high in prejudice are more likely than those low in prejudice to perceive an external social norm of tolerance of discrimination against the disparaged group. Furthermore, people who are high in prejudice tend to have more weakly internalized non-prejudiced convictions compared to people who are low in prejudice (Monteith, Devine, \& Zuwerink, 1993). They are primarily motivated by external forces (social norms) to respond without prejudice (e.g., Devine, Monteith, Zuwerink, \& Elliot 1991; Devine, Plant, Amodio, Harmon-Jones, \& Vance, 2002; Plant \& Devine, 1998). As a result, people high in prejudice are more likely to use external norms as a standard defining how one ought to behave (Monteith, Deneen, \& Tooman, 1996; Wittenbrink \& Henly, 1996). Highly prejudiced people suppress prejudice when social norms dictate restraint; they release prejudice when the norms communicate approval to do so. Ford's (2000) research lends support to this idea. He found that sexist jokes increased tolerance of a sexist event only for 
participants high in hostile sexism who adopted a non-critical mindset when listening to sexist jokes. For participants low in hostile sexism there was no difference in tolerance of a sexist event related to critical mindset.

Like people who are high in other forms of prejudice, people who are high in hostile sexism are motivated to suppress prejudice against women to avoid social sanctions, not because of internalized convictions (Ford \& Lorion, 2000). However, Ford and Lorion (2000) found that these effects did not extend to those high in benevolent sexism. Specifically, those high in benevolent sexism did not show lower internal motivation to respond to women without prejudice than those low in benevolent sexism. Because benevolent sexism is characterized by the idealization rather than derision of women, people high in benevolent sexism might be more likely than those high in hostile sexism to internalize nonsexist standards of conduct.

Because people who are high in hostile sexism are primarily externally motivated to respond without prejudice, they are more likely to assent to the norm implied by sexist humor that it is acceptable to make light of sex discrimination and not take it seriously in the imme diate context. As reviewed earlier, research shows that people approve of sexist humor to the extent that they have sexist attitudes (e.g., Butland \& Ivy, 1990; Greeenwood \& Isbell, 2002; LaFrance \& Woodzicka, 1998).

Ford, Boxer, Armstrong and Edel (2008) addressed more directly the processes that mediate the effects of sexist humor on men's willingness to discriminate against women. They found that, upon exposure to sexist comedy skits, men who were high in hostile sexism were more likely than those who were low in hostile sexism to perceive a norm of tolerance of sexism in the immediate context, and they were more likely to use that norm to guide their own reactions to a sexist event. Hostile sexism predicted the amount of money participants cut from the budget of a women's organization relative to four other student organizations upon exposure to sexist comedy skits but not neutral comedy skits. A perceived local norm of approval of funding cuts for the women's organization mediated the relationship between hostile sexism and discrimination against the women's organization.

Future directions for the Study of Indirect Effects

Sexist humor as a form of gender harassment at work. Gender harassment has been shown to have a cumulative, eroding effect on the women's mental health. Even low-levels of gender harassment at work are associated with decreased psychologic al well-being and life satisfaction (Schneider, Swam, \& Fitzgerald, 1997). No research to date has directly examined long-term emotional consequences of 
exposure to sexist humor at work. However, insofar as sexist humor at work constitutes a form of gender harassment, it is possible that repeated exposure to it negatively affects women's psychological well-being. Thus, we propose that an important project for future research is to more fully delineate the long-term emotional consequences for women of repeated exposure to sexist humor at work.

Sexist humor, discrimination against women and prejudiced norm theory. Sexist humor may derive power to trivialize sexism and foster a normative climate of tolerance of sex discrimination from the ambiguity of society's attitudes toward women. The blatant sexism and open discrimination that existed prior to the civil rights movement of the 1960s and the feminist movement of the 1970s has been largely replaced by subtle, more complex forms of sexism such as "ambivalent sexism" (Glick \& Fiske, 1996), "modern sexism" (Swim, Aikin, Hall, \& Hunter, 1995), and "neo-sexism" (Tougas, Brown, Beaton, \& Joly, 1995). These contemporary models suggest that attitudes toward women have become ambivalent, containing both positive and negative components. That is, many Americans consciously espouse egalitarian values and non-prejudiced attitudes while possessing negative sentiments tow ard women.

As a result of this ambivalence, society does not consider sexism as being completely unacceptable as it might prejudice toward boy scouts or firefighters (Crandall \& Ferguson, 2005). On the other hand, society does not treat sexism as being completely acceptable and free to be expressed openly as it might prejudice toward criminals or White supremacy groups (Crandall \& Ferguson, 2005). Sexism is in an "in between" state of acceptability; it is in what Crandall and Ferguson (2005) refer to as a state of "shifting social acceptability." That is, sexism is shifting from being completely acceptable to being completely unacceptable. Thus, sexism is conditional. It must be suppressed under most circumstances. However, it may be released if immediate social norms justify its expression (Crandall \& Eshleman, 2003). In such a context, one can release prejudice and be spared the recognition that he or she had behaved inappropriately (Gaertner \& Dovidio, 1986).

Research guided by prejudiced norm theory suggests that sexist humor creates a normative context that justifies the release of prejudice against women. However, we propose that important theoretical questions remain to be addressed in future research.

First, it is possible that disparagement humor has the power to release prejudice against only groups for whom society's attitudes are ambivalent-those groups in the "in between" state of acceptability against whom the expression of prejudice is 
dependent on imme diate social norms to justify it (e.g., women, African-Americans). In contrast, for groups like criminals or White supremacists, society does not promote a general norm of prejudice suppression. Instead, society treats prejudice against such groups as completely acceptable and free to be expressed openly. Thus, the expression of prejudice against such groups should not be dependent on events like disparagement humor to create a local norm to justify it. As a result, exposure to disparagement humor should have little effect on the release of prejudice against them.

Second, research guided by prejudiced norm theory has focused largely on the social consequences of sexist humor for men. For men, the relationship between sexist attitu des and responses to sexist humor is straightforward: the higher men are in hostile sexism, the more they are amused by sexist humor and the more likely they are to express prejudice in the context of sexist humor (Ford et al., 2008). For women, however, the relationship between sexist attitudes and responses to sexist humor may be more complicated. In some cases, sexist humor might foster discrimination against disliked groups of women as it does for men. In others it might create emotionally challenging or distressing environments.

Of particular interest is how women high in benevolent sexism would fit into prejudice norm theory. As Greenwood and Isbell (2002) pointed out, amusement reactions to sexist humor by women high in benevolent sexism resemble ratings made by feminists. It is likely that the subgroup of women (e.g., feminists, housewives, etc.) that is being targeted is especially important when examining how sexist humor affects women high in benevolent sexism. We expect that women high in benevolent sexism feel that some women, particularly women in the non-norm challenging subgroups, should be protected while others, women who challenge existing norms, should not.

Third, research could examine the possibility that others' reactions to sexist humor contribute to the degree to which it functions as a releaser of prejudice. Young and Frye (1966) argued that a confederate's laughter enhanced amuse ment in response to sexist humor by relaxing the "social taboos" associated with expression of sexist sentiments (p. 754). By displaying cues of approval of sexist humor, recipients might further encourage both men and women high in hostile sexism to adopt a noncritical mindset for interpreting the underlying derision and to perceive a shared norm of tolerance of discrimination against feminist women thus further promoting discrimination. On the other hand, others' disapproval of the humor might make salient a discrepancy between personal affective reactions tow ard feminist women and prevailing normative standards. Under such conditions, men and women high 
in hostile sexism might experience self-directed negative affect (e.g., guilt) and suppress rather than release prejudice against feminist women.

\section{Conclusion}

As Charles Barkley's joke on national television attests, sexist humor is pervasive in contemporary society. It appears in all forms of mass media, from television to the Internet. Paradoxically, as sexist humor becomes increasingly pervasive, the public and social scientists alike have increasingly recognized sexist humor as an insidious expression of sexism. Whether through cultivating distressing work environments for women (Boxer \& Ford, in press; Duncan, Smeltzer, \& Leap, 1990; Hemmasi, et al., 1994) or facilitating tolerance of sexism and discrimination among men (Ford, 2000; Ford et al., 2008; Ford \& Ferguson, 2004; Ford et al., 2001 ) sexist humor can have detrimental social consequences.

With the growing awareness that sexist humor can function as a potential tool of prejudice and discrimination, there is a clear need for social scientists to continue to conduct empirical research to illuminate the potentially complex emotional responses that people may have to sexist humor. There is also a clear need for researchers to continue to conduct research in an effort to further delineate the broader social consequences of sexist humor, and thus help us better understand how sexist humor shapes social interaction.

The present research offers one contribution to this effort. Our first goal in writing this paper was to provide researchers with a conceptual framework for organizing and evaluating empirical research and theories on the immediate or direct effects of sexist humor as well as on the broader, indirect social conse quences of sexist humor. Our second goal was to raise important issues or questions that require further empirical research or theoretical development. We hope that this paper will cultiv ate further interest in theoretically guided empirical research on sexist humor.

\section{References}

Attardo, S. (1993). Violation of conversational maxims and cooperation: The case of jokes. Journal of Pragmatics, 19, 537-558.

Baker, D. D., Terpstra, D. E., \& Larntz, K. (1990). The influence of individual characteristics and severity of harassing behavior on reactions to sexual harassment. Sex Roles, 22 (5/6), 305-325. 
Barron, M. L. (1950). A content analysis of intergroup humor. American Sociological Review, 15, 88-94.

Bell, M. P., Mclaughlin, M. E., \& Sequeira, J. M. (2002). Discrimination, harassment, and the glass ceiling: Women executives as change agents. Journal of Business Ethics, 37, 6576.

Berlyne, D. E. (1972). Humor and its kin. In J. H. Goldstein \& P. E. McGhee (Eds.), The psychology of humor (pp. 43-60). New York, NY: Academic Press.

Bill, B., \& Naus, P. (1992). The role of humor in the interpretation of sexist incidents. Sex Roles, 27, 645-664.

Bourhis, R. Y., Gadfield, N. J., Giles, H., \& Tajfel, H. (1977). Context and ethnic humor in intergroup relations. In A. J. Chapman \& H. C. Foot (Eds.), It's a funny thing, humor (pp. 261-265). Elmsford, NY: Pergamon Press.

Boxer, C. F., \& Ford, T. E. (2010). Sexist humor in the workplace: A case of subtle harassment. In J. Greenberg (Ed.), Insidious workplace behavior (pp. 175-206). Boca Raton, FL: Routledge, Taylor \& Francis Group.

Brodzinsky, D. M., Barnet, K., \& Aiello, J. R. (1981). Sex of subject and gender identity as factors in humor appreciation. Sex Roles, 7, 561-573.

Butland, M. J., \& IVY, D. K. (1990). The effects of biological sex and egalitarianism on humor appreciation: Replication and extension. Journal of Social Behavior and Personality, 5, 353-366.

Cantor, J. R., \& Zillman, D. (1973). Resentment toward victimized protagonists and severity of misfortunes they suffer as factors in humor appreciation. Journal of Experimental Research in Personality, 6, 321-329.

Chapman, A. J., \& Gadfield, N. J. (1976). Is sexual humor sexist? Journal of Communication, 26, 141-153.

Crandall, C. S., \& Eshleman, A. (2003). A justification-suppression model of the expression and experience of prejudice. Psychological Bulletin, 129, 414-446.

Crandall, C. S., \& Ferguson, M. A. (2005, September). Prejudice and prejudices: Resistance to social change is at the heart of prejudice. Paper presented at the conference "Looking Toward the Future: Discrimination and Prejudice in the $21^{\text {st }}$ Century," Madison, WI. 
Devine, P. G., Monteith, M. J., Zuwerink, J. R., \& Elliot, A. J. (1991). Prejudice with and without compunction. Journal of Personality and Social Psychology, 60, 817-830.

Devine, P. G., Plant, E. A., Amodio, D. M., Harmon-Jones, E., \& Vance, S. L. (2002). The regulation of explicit and implicit race bias: The role of motivations to respond without prejudice. Journal of Personality and Social Psychology, 82, 835-848.

Duncan, W. J. (1982). Humor in management: Prospects for administrative practice and research. Academy of Management Review, 7, 136-142.

Duncan, W. J., Smeltzer, L. R., \& Leap, T. L. (1990). Humor and work: Applications of joking behavior to management. Journal of Management, 16, 255-278.

Estrada, J. (2009, May 26). Sexism in the media: I am woman, hear me roar. New University. Retrieved from http://www.newuniversity.org

Eyssel, F., \& Bohner, G. (2007). The rating of sexist humor under time pressure as an indicator of spontaneous sexist attitudes. Sex Roles, 57, 651-660.

Ferguson, M. A., \& Ford, T. E. (2008). Disparagement humor: A theoretical and empirical review of psychoanalytic, superiority, and social identity theories. Humor: International Journal of Humor Research, 21, 283-312.

Fine, G. A. (1983). Sociological approaches to the study of humor. In P. E. McGhee \& J. H. Goldstein (Eds.), Handbook of humor research (pp. 159-181). New York, NY: SpringerVerlag.

Fitzgerald, L. F., Swan, S., \& Fischer, K. (1995). Why didn't she just report him? The psychological and legal implications of women's response to sexual harassment. Journal of Social Issues, 51 (1), 117-137.

Ford, T. E. (2000). Effects of sexist humor on tolerance of sexist events. Personality and Social Psychology Bulletin, 26, 1094-1107.

Ford, T. E., Boxer, C. F., Armstrong, J., \& Edel, J. R. (2008). More than just a joke: The prejudice-releasing function of sexist humor. Personality and Social Psychology Bulletin 32, 159-170.

Ford, T. E., \& Ferguson, M. (2004). Social consequences of disparagement humor: A prejudiced norm theory. Personality and Social Psychology Review, 8, 79-94. 
Ford, T. E., Johnson, F. J., Blevins, J., \& Zepeda, C. (1999, August). Effects of the gender of the joke-teller upon perceptions of offensiveness of sexist jokes. Paper presented at the annual meeting of the American Sociological Association, Chicago, IL.

Ford, T. E., \& Lorion, J. (2000, November). Perceptions of social norms implied by sexist humor: The moderating role of hostile sexism. National Communication Association, seattle, WA.

Ford, T. E., Wentzel, E. R., \& Lorion, J. (2001). Effects of exposure to sexist humor on perceptions of normative tolerance of sexism. European Journal of Social Psychology, 31, 677-691.

Frazier, P. A., Cochran, C. C., \& Olson, A. M. (1995). Social science research on lay definitions of sexual harassment. Journal of Social Issues, 51 (1), 21-37.

Gaertner, S. L., \& Dovidio, J. F. (1986). The aversive form of racism. In J. F. Dovidio \& S. L. Gaertner, S. L. (Eds.), Prejudice, discrimination, and racism (pp. 61-89). San Diego, CA: Academic Press.

Glick, P., \& Fiske, S. T. (1996). The ambivalent sexism inventory: Differentiating hostile and benevolent sexism. Journal of Personality and Social Psychology, 70, 491-512.

Gollob, H. F., \& Levine, J. (1967). Distraction as a factor in the enjoyment of aggressive humor. Journal of Personality and Social Psychology, 5, 368-372.

Greenwood, D., \& Isbell, L. M. (2002). Ambivalent sexism and the dumb blonde: Men's and women's reactions to sexist jokes. Psychology of Women Quarterly 26, 341-50.

Gruner, C. R. (1997). The game of humor: A comprehensive theory of why we laugh. New Brunswick, NJ: Transaction Publishers.

Gutek, B. A. \& Koss, M. P. (1993). Changed women and changed organizations: Consequences of and coping with sexual harassment. Journal of Vocational Behavior, 42, 28-48.

Hansen, C. H., \& Hansen, R. D. (1988). How rock music videos can change what is seen when boy meets girl: Priming stereotypic appraisal of social interactions. Sex Roles, 19, 287-316.

Hassett, J., \& Houlihan, J. (1979). Different jokes for different folks. Psychology Today, 12, 64-71. 
Hemmasi, M., \& Graf, L. (1998). Sexual and sexist humor in the work place: Just "good fun" or sexual harassment? Proceedings of Decision Sciences Institute (pp. 455-457). Las Vegas, NV: DSI.

Hemmasi, M., Graf, L. A., \& Russ, G. S. (1994). Gender-related jokes in the workplace: Sexual humor or sexual harassment? Journal of Applied Social Psychology, 24, 1114-1128.

Henkin, B., \& Fish, J. M. (1986). Gender and personality differences in the appreciation of cartoon humor. Journal of Psychology, 120 (2), 157-175.

Husband, C. (1977). The mass media and the functions of ethnic humor in a racist society. In A. J. Chapman \& Foot, H. C. (Eds.), Its a funny thing, humor (pp. 267-272). Elmsford, NY: Pergamon Press.

Johnson, A. M. (1990). The "only joking" defense: Attribution bias or impression management? Psychological Reports, 67, 1051-1056.

Kane, T. R., Suls, J., \& Tedeschi, J. T. (1977). Humour as a tool of social interaction. In A. J. Chapman \& Foot, H. C. (Eds.), Its a funny thing, humor (pp. 13-16). Elmsford, NY: Pergamon Press.

Keith-Spiegel, P. (1972). Early conceptions of humor: Varieties and issues. In J. H. Goldstein \& P. E. McGhee (Eds.), The psychology of humor (pp. 4-39). New York: Academic Press.

La Fave, L. (1972). Humor judgments as a function of reference groups and identification classes. In J. H. Goldstein and P. E. McGhee (Eds.), The psychology of humor (pp. 195210). New York: Academic Press.

La Fave, L., Haddad, J., \& Maesen, W. A. (1976/1996). Superiority, enhanced self-esteem, and perceived incongruity humor theory. In A. J. Chapman \& H. C. Foot (Eds.), Humor and laughter: Theory, research, and applications (pp. 63-91). New York: Wiley.

La Fave, L., McCarthy, K., \& Haddad, J. (1973). Humor judgments as a function of identification classes: Canadian vs. American. Journal of Psychology, 85, 53-59.

LaFrance, M., \& Woodzicka, J. A. (1998). No laughing matter: Women's verbal and nonverbal reactions to sexist humor. in J. Swim \& C. Stagnor (Eds.), Prejudice: The target's perspective (pp. 61-80). San Diego, CA: Academic Press.

Lewin, T. (1995, February 22). Chevron settles harassment charges. New York Times, p. 16. 
Losco, J., \& Epstein, S. (1975). Humor preferences as a subtle measure of attitudes tow ards the same and the opposite sex. Journal of Personality, 43, 321-334.

Love, A. M., \& Deckers, L. H. (1989). Humor appreciation as a function of sexual, aggressive, and sexual content. Sex Roles, 20 (11/12), 649-654.

Machan, D. (1987). What's black and blue and floats in the Monongahela River? Forbes, 140, 216-220.

McGhee, P. E., \& Duffey, N. S. (1983). The role of identity of the victim in the development of disparagement humor. Journal of General Psychology, 108, 257-270.

Monteith, M. J., Deenen, N. E., \& Tooman, G. D. (1996). The effect of social norm activation on the expression of opinions concerning gay men and Blacks. Basic and Applied Social Psychology, 18, 267-288.

Monteith, M. J., Devine, P. G., \& Zuwerink, J. R. (1993). Self-directed versus other-directed affect as a consequence of prejudice-related discrepancies. Journal of Personality and Social Psychology, 64, 198-210.

Moore, T. E., Griffiths, K., \& Payne, B. (1987). Gender, attitudes towards women, and the appreciation of sexist humor. Sex Roles, 16 (9/10), 521-531.

Morreall, J. (1983). Taking laughter seriously. Albany, NY: State U niversity of New York.

Mundorf, N., Bhatia, A., Zillman, D., Lester, P., \& Robertson, S. (1988). Gender differences in humor appreciation. Humor: International Journal of Humor Research, 1, 231-243.

Nelson, T. D. (2006). The psychology of prejudice. Boston, MA: Allyn and Bacon.

Neuliep, J. W. (1987). Gender differences in the perception of sexual and nonsexual humor. Journal of Social Behavior and Personality, 2 (3), 345-351.

Olson, J. M., Maio, G. R., \& Hobden, K. L. (1999). The (null) effects of exposure to disparagement humor on stereotypes and attitudes. Humor: International Journal of Humor Research, 12, 195-219.

Olson, J. M., \& Roese, N. J. (1995). The perceived funniness of humorous stimuli. Personality and Social Psychology Bulletin, 21 (9), 908-913. 
Plant, E. A., \& Devine, P. G. (1998). Internal and external motiv ation to respond without prejudice. Journal of Personality and Social Psychology, 75, 811-832.

Priest, R. F., \& Wilhelm, P. G. (1974). Sex, marital status, and self/actualization as factors in the appreciation of sexist jokes. The Journal of Social Psychology, 92, 245-249.

Ryan, K., \& Kanjorski, J. (1998). The enjoyment of sexist humor, rape attitudes, and relationship aggression in college students. Sex Roles, 38, 743-56.

Schneider, K. T., Swan, S., \& Fitzgerald, L. F. (1997). Job-related and psychological effects of sexual harassment in the workplace: Empirical evidence from two organizations. Journal of Applied Psychology, 82 (3), 401-415.

Sev'er, A., \& Ungar, S. (1997). No laughing matter: Boundaries of gender-based humour in the classroom. Journal of Higher Education, 68, 87-105.

Smeltzer, L. R., \& Leap, T. L. (1988). An analysis of individual reactions to potentially offensive jokes in work settings. Human Relations, 41, 295-304.

Swim, J. K., Aiken, K. J., Hall, W. S., \& Hunter, B. A. (1995). Sexism and racism: Oldfashioned and modern prejudices. Journal of Personality and Social Psychology, 68, 199214.

Swim, J. K., \& Stangor, C. (Eds). (1998). Prejudice: The target's perspective. San Diego, CA: Academic Press.

Tajfel, H., \& Turner, J. C. (1986). The social identity theory of intergroup behavior. In W. G. Austin \& S. Worchel (Eds.), Psychology of intergroup relations (pp. 7-24). Chicago, IL: Nelson-Hall.

Terpstra, D. E., \& Baker, D. D. (1989). The identification and classification of reactions to sexual harassment. Journal of Organizational Behavior, 10, 1-14.

Thomas, C. A. \& Esses, V. M. (2004). Individual differences in reactions to sexist humor. Group Processes \& Intergroup Relations, 7, 89-100.

Tougas, F., Brown, R., Beaton, A. M., \& Joly, S. (1995). Neosexism: Plus ça change, plus c'est pareil. Personality and Social Psychology Bulletin, 21, 842-849. 
Weston, C. M., \& Thomsen, C. J. (1993, August). No joking matter: Sex-typed comedy perpetuates traditional views of women. Paper presented at the American Psychological Association Conference, Toronto, Canada.

Wicker, F. W., Barron, W. L., III, \& Willis, A. C. (1980). Disparagement humor: Dispositions and resolutions. Journal of Personality and Social Psychology, 39, 701-709.

Wittenbrink, B. \& Henly, J. R. (1996). Creating social reality: Informational social influence and content of stereotypic beliefs. Personality and Social Psychology Bulletin, 22, 598610.

Young, R. D., \& Frye, M. (1966). Some are laughing; Some are not-Why? Psychological Reports, 18, 747-754.

Zillman, D. (1983). Disparagement humor. In P. E. McGhee \& J. H. Goldstein (Eds.), Handbook of humour research, vol. 1. New York: Springer-Verlag.

Zillmann, D., \& Cantor, J. R. (1976/1996). A disposition theory of humor and mirth. In A. J. Chapman \& H. C. Foot (Eds.), Humor and laughter: Theory, research and applications (pp. 93-116). New York: Wiley.

About the authors:

Julie A. Woodzicka is an Associate Professor of Psychology at Washington and Lee University. Her research interests include the effects of sexist humor, nonverbal responses to prejudice, stereotypes of and prejudice against Atheists, and perceptions of privilege.

Address for correspondence: Julie Woodzicka, Department of Psychology, Washington and Lee University, Lexington, VA 24450 USA

E-mail:woodzickaj@wlu.edu

Thomas E. Ford is a Professor of Psychology at Western Carolina University. His research interests include disparagement humor and discrimination, humor and coping with stress, the relationship between religion and prejudice, and unintentional racism and stereotype threat in educational settings.

Thomas E. Ford, Department of Psychology, Western Carolina University, Cullowhee, NC 28723 USA, tford@wcu.edu 